\title{
Marketing and Production of Fruits and Vegetables in India
}

\author{
Neeraj $^{1 *}$, Akshay Chittora ${ }^{2}$, Vinita Bisht ${ }^{1}$ and Vishal Johar ${ }^{3}$ \\ ${ }^{1}$ Department of Agriculture, Mewar University, Gangrar, Chittorgarh, Rajasthan-312901, India \\ ${ }^{2}$ Department of Horticulture, MPUA\&T, Udaipur-313001, India \\ ${ }^{3}$ Department of Forestry, CCS Haryana Agricultural University, Hisar-125004, Haryana, India \\ *Corresponding author
}

\begin{tabular}{|c|}
\hline Keywords \\
\hline $\begin{array}{l}\text { Fruits, Vegetables, } \\
\text { Horticulture, } \\
\text { Production, India. }\end{array}$ \\
\hline Article Info \\
\hline $\begin{array}{l}\text { Accepted: } \\
\text { 26 August } 2017 \\
\text { Available Online: } \\
\text { 10 September } 2017\end{array}$ \\
\hline
\end{tabular}

\section{Introduction}

India is considered as the fruit and vegetable basket of the world. It being a home of wide variety of fruits and vegetables holds a unique position in production figures among all countries. It is the second largest producer of fruits after China in the world with an annual production of 88.98 million tonnes from an area of 7.21 million hectares. It is also the second largest producer of vegetables next to China with an annual production of 162.89 million tonnes from an area of 9.39 million hectares (Anonymous, 2014). This is possible because of agro climatic variations, enormous biodiversity, fertile soil and a large cultivable area. Indian agriculture has reached at the peak production level of various crops but the nutritional security is still a big question mark in front of all planners and researchers. India accounts for 16 per cent of world production of vegetables and 11 per cent of the world's 
fruit production. It is the largest producer of mangoes, bananas, papaya, sapota, chillies, ginger and okra etc. The horticulture sector has witnessed a tremendous growth as a result of investment through National Horticulture Mission (NHM) and a number of other programmes (Singh and Toppo, 2010). Fruits and vegetables play an important role in agriculture and industrial economy. These crops, which are among the perishable commodities, are important ingredients of human diet. Fruits are one of the oldest forms of food known to human being. Moreover, in a country like India, where $20-40$ per cent of the population is vegetarian, the need of fruits and vegetables in our diet is evident. Almost all fruits and vegetables contain varying amount of food contents, such as carbohydrates, fats, proteins, vitamins, minerals, etc. While carbohydrates, fats and proteins can be derived from other foods like cereals, sugar, pulses and oil seeds also, but vitamins and minerals are mainly obtained from fruits and vegetables. Vegetables are plant parts varying in their water, protein, vitamin, mineral and carbohydrate contents. Green leafy vegetables are good source of folic acid and iron. Expenditure on vegetables forms 11 per cent of total food expenditure in the rural India and 10.5 per cent in urban India (Singh and Suhag, 2010).

Presently horticulture contributes 28 per cent of agricultural GDP (Gross domestic product). Country has emerged as the world's largest producer of coconut and tea and the second largest exporter of coffee, cashew and spices. Only 2 per cent of horticulture produce is processed, 0.4 per cent is exported and 22 per cent is lost or get wasted in market chain (Amarasinghe et al., 2008). Exports of fresh and processed fruits, vegetables, cut flowers, dried flowers have also been picking up. The ongoing economic reforms in India are likely to result in structural changes in agriculture particularly in favour of fruit and vegetable crops, which has great potential to increase farm income as well as nutritional status of the citizens of the nation. On demand side, the increasing purchasing power and more working women have positive impact on changes in life style and food consumption habits of Indian population (Amarasinghe et al., 2007). The National Sample Survey (NSS) suggests that there has been a decline in per capita cereal consumption since the early 1970s. It is estimated that to fulfill the increased demand for high value horticultural crops in South Asia, the production of these crops has to be increased by 142 per cent by 2020.

The Fruits and Vegetables $(\mathrm{F} \& \mathrm{~V})$ sector has been a driving force in stimulating a healthy growth trend in Indian agriculture. Given the rising share of high value commodities in the total value of agricultural output and their growth potential, this segment is likely to drive agricultural growth in the years to come (ASSOCHAM, 2013).

It plays a unique role in India's economy by improving the income of the rural people. Cultivation of fruit and vegetables is substantially more labor-intensive than growing cereal crops and offers more postharvest opportunities to add value (Joshi et al., 2004; Weinberger and Lumpkin, 2005). The efficiency of marketing for fruits and vegetables in India has been of significant concern in the recent years. Poor efficiency in the marketing channels and inadequate marketing infrastructure are believed to be the cause of not only high and fluctuating consumer prices, but also a little amount expended by consumer reached to the farmers (Kaul, 1997). Indian farmers typically depend heavily on middlemen particularly in fruits and vegetable marketing. The producers and the consumers often get a poor deal and middlemen control the market, but do not add much value. There is also massive wastage, 
deterioration in quality as well as frequent mismatch between demand and supply both spatially and over time.

The study also made an attempt to identify the prevailing value chain from the Farmer $\rightarrow$ Pre-harvest contractor $\rightarrow$ Commission Agent $\rightarrow$ Wholesaler $\rightarrow$ Retailer $\rightarrow$ Consumer in terms of costs, prices and their shares in the selected markets.

\section{Emerging challenges for horticulture}

The organized supply of a wide range of reasonably priced horticultural crops in most developed countries has led to a marked gratification about the need for ongoing research and development (R\&D) programmes in horticulture. Consequently, many governments world-wide have scaled back funding for food production (at least in the applied areas of R\&D) and unfortunately, most research- driven universities have now disbanded horticulture/horticultural science departments and combined them into plant science departments with a very strong focus on the molecular sciences. On the contrary, the basic necessity for research on horticultural crops has not decreased, rather the challenges have increased in complexity given the existing consumer demands for affordability, safety and continuity of supply; increasing needs to achieve sustainable practices; requirements to deal with challenges originating from a more uneven climate, the loss of productive soils through urban intrusion, and the loss of low-cost labour. Hence, specific priorities, as given below need to be identified for horticultural research to meet such challenges.

With ever increasing public consciousness, the promotion of healthy habit benefits through the eating of various fresh and dried fruits and vegetables as well as their juices, dried products and extracts-many of which have extensive on-label claims (Martin and Luxton, 2005) is on the rise. However many such claims have not in fact been clinically confirmed and regulators are increasingly requiring label claims to either be substantiated or removed. Obviously, to correctly determine the presumed health benefits in many fruits and vegetables would be an interesting area of endeavor where there is a union of horticultural science with nutritional and medical research. Further, owing to increased consumer interest towards the eating of fresh rather than frozen produce, another challenge for horticultural science is to improve methods for short term storage so that best quality is retained rather than to focus on longer-term storage for prolonged marketing. The concept of sustainability of horticultural crops narrate both to the use of resources, such as water and nutrients, in a way which considers future needs, and the accountable use of objectionable compounds such as pesticides which will not compromise the quality of the environment.

\section{Overview of fruit and vegetable economy of India}

This section gives a brief account of fruits and vegetables economy of India. This is examined in terms of the production and productivity of major fruits and vegetables at the national level as well as in various states along with the export and import status.

\section{Fruits and vegetables production in India}

India ranks second in the world in the combined production of fruits and vegetables. Out of 654 million tons of fruit production in the world, India accounts for about 89 million tons sharing about $13.6 \%$ of world's production. Of the 1160 million tons of vegetables produced in the world, India produces as much as 163 million tons and so India's share in the world's vegetable market 
is about 14 per cent. To boost the production and productivity of vegetables and fruits in the country, government is implementing Horticulture Mission for North East and Himalayan States (HMNEH) including Uttarakhand and National Horticulture Mission (NHM) in the remaining states under Mission for Integrated Development of Horticulture (MIDH). These schemes provide support for production of planting material, high yielding variety vegetable seed production, vegetable cultivation, rejuvenation of senile orchards, protected cultivation, creation of water resources, creation of infrastructure to prevent postharvest losses of horticultural crops and for adoption of integrated nutrient management (INM)/integrated pest management (IPM).

The vast production base offers India tremendous opportunities for export. During 2015-16, India exported fruits and vegetables worth Rs. 8,391.41 crores which comprised of fruits worth Rs. 3,524.50 crores and vegetables worth Rs. 4,866.91 crores. Mangoes, walnuts, grapes, bananas, pomegranates account for larger portion of fruits exported from the country while onions, okra, bitter gourd, green chillies and potatoes contribute largely to the vegetable export basket. The major destinations for Indian fruits and vegetables are UAE, Bangladesh, Malaysia, Netherland, Sri Lanka, Nepal, UK, Saudi Arabia, Pakistan and Qatar. Though India's share in the global market is still nearly $1 \%$ only, there is increasing acceptance of horticulture produce from the country. This has occurred due to concurrent developments in the areas of state-of-the-art cold chain infrastructure and quality assurance measures (APEDA, 2017).

\section{Fruit and vegetable marketing}

Marketing of horticultural crops is quite complex and risky due to the perishable nature of the produce, seasonal production and bulkiness. The spectrum of prices from producer to consumer, which is an outcome of demand and supply of transactions between various intermediaries at different levels in the marketing system, is also unique for fruits and vegetables. Moreover, the marketing arrangements at different stages also play an important role in price levels at various stages viz. from farm gate to the ultimate user. These features make the marketing system of fruits and vegetables to differ from other agricultural commodities, particularly in providing time, form and space utilities. While the market infrastructure is better developed for food grains, fruits and vegetables markets are not that well developed and markets are congested and unhygienic. The markets in many of the major cities in some states are not covered by market legislation and continue to function under civic body as well as private ownership.

Some studies have shown that producers' share in consumers' rupee is comparatively lower for perishable crops (Saikia, 1985; Singh, 1985; Ashturker and Deole, 1985). This could be due to a variety of factors such as number of intermediaries, cost of various market functions rendered by intermediaries, spread of location of the producers and consumers. Further the degree of perishability, variety and quality, and various market imperfections, market infrastructure etc. also influence the marketing costs and price levels. Producers' share was found to be relatively high in areas where better infrastructure facilities for marketing were made available. Some studies have cited examples of an improvement in producers' share over a period of time due to improvement in market infrastructure, such as cold storage facilities. On the other hand the low share of consumers' rupee for potato growers in different parts of the country may be due to high margins of intermediaries. 
Producers' share also often varied during peak and lean seasons (Subbanarasaiah, 1991). Substantial variation in producers' share in consumers' rupee for fruits and vegetables was also observed even in the same location itself.
Damage cost, intermediatories exploitative practices, perishability of product, transportation cost and high storage cost etc. have been reported to be the major problems of marketing vegetables and fruits in farmers' market (Kumar, 2012).

\section{Major fruits producing countries}

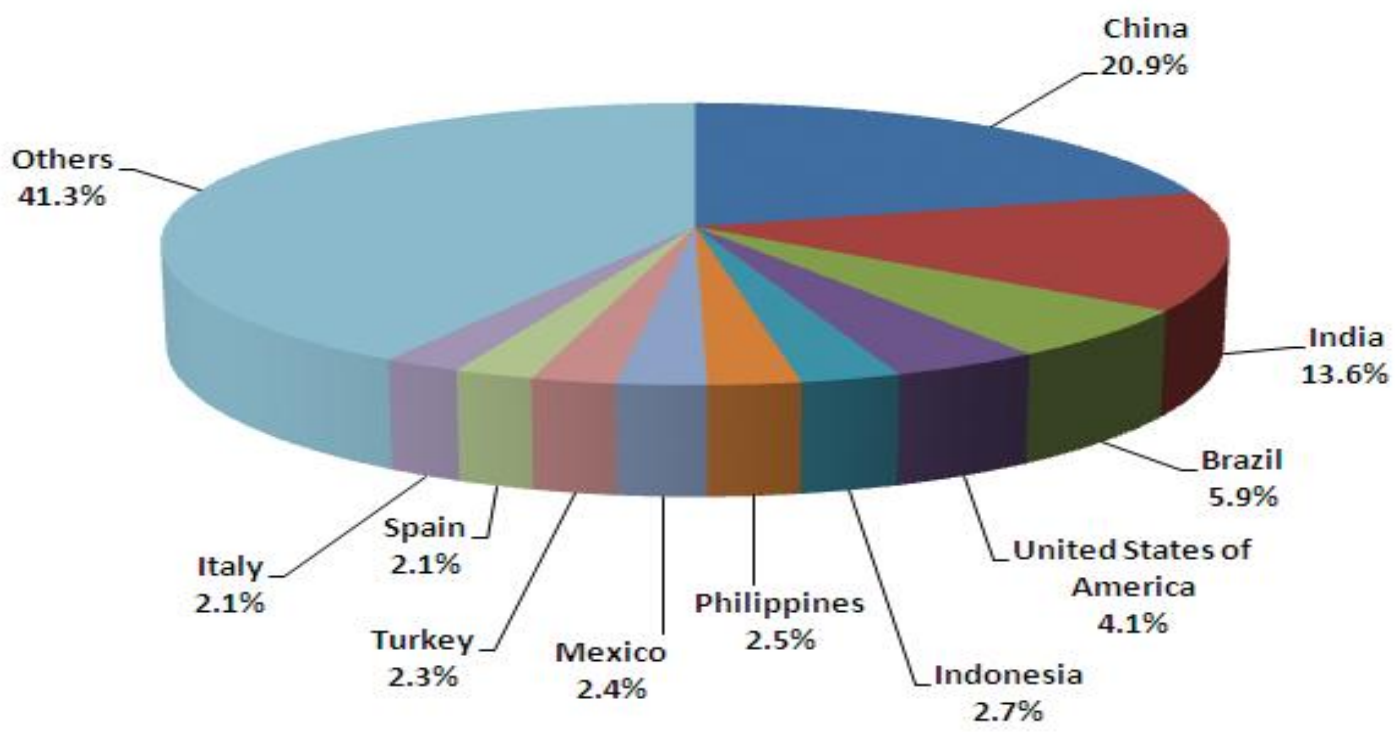

Major vegetables producing countries

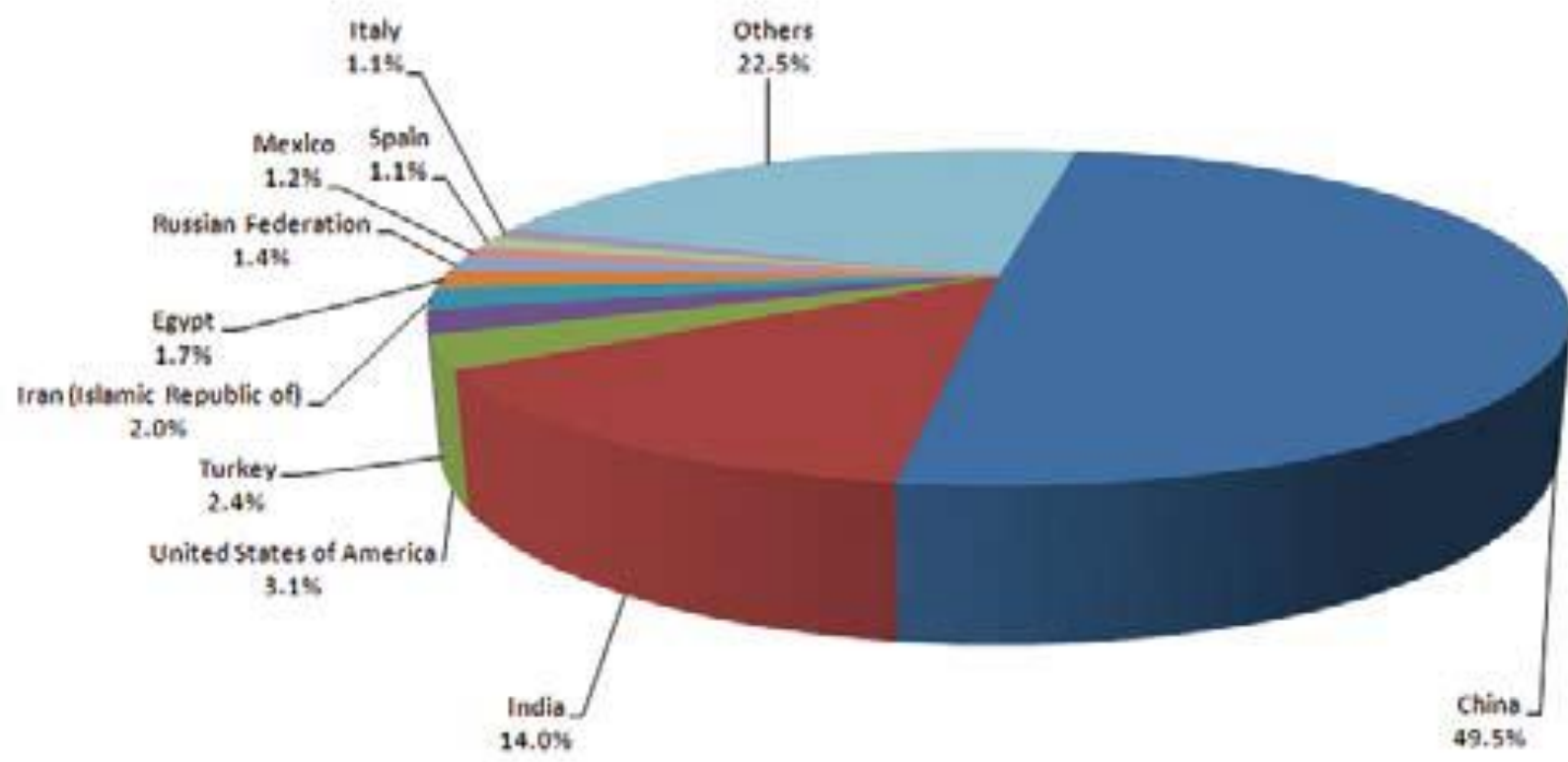




\section{Trends in Fruits and Vegetables Production in India}

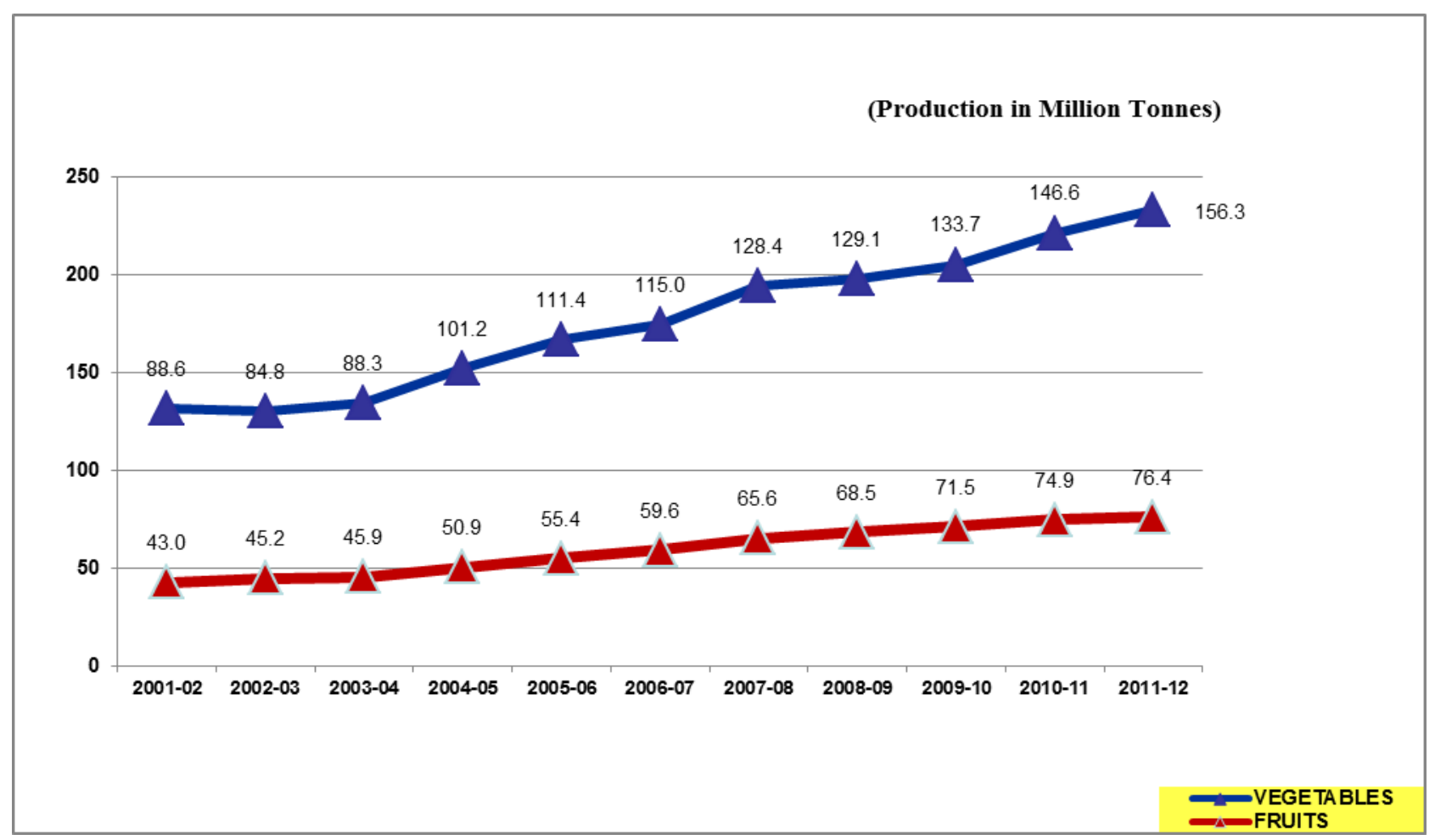

Source: D/o Agriculture \& Cooperation, GOI

Table.1 Selected vitamins and other bioactive components in fruits and vegetables

\begin{tabular}{|c|c|}
\hline \multicolumn{2}{|l|}{ Vitamins } \\
\hline Folacin: & $\begin{array}{l}\text { Avocado, orange, asparagus, black bean, black-eyed pea, Brussels sprout, chive, endive, } \\
\text { green pea, kidney bean, mustard greens, navy bean, okra, soybean, spinach, turnip greens }\end{array}$ \\
\hline Vitamin C: & $\begin{array}{l}\text { Blackberry, blueberry, cantaloupe, cranberry, grapefruit, kiwi fruit, lemon, lime, mango, } \\
\text { orange, papaya, peach, raspberry, strawberry, tangerine, broccoli, Brussels sprout, } \\
\text { cabbage, cauliflower, kale, kohlrabi, spinach, sweet red/green pepper, tomato }\end{array}$ \\
\hline \multicolumn{2}{|c|}{ Other bioactive components } \\
\hline Allicin: & Chives, garlic, leek, onion, shallot \\
\hline Capsaicin: & Chili pepper \\
\hline Carotenoids: & $\begin{array}{l}\text { Carrot, pumpkin, sweet potato, apricot, cantaloupe, guava, mango, peach, persimmon, } \\
\text { grapefruit, asparagus, beet greens, broccoli, Brussels sprouts, cabbage, carrot, cassava } \\
\text { leaves }\end{array}$ \\
\hline Lycopene: & Guava, red/pink grapefruit, watermelon, tomato \\
\hline Lutein: & $\begin{array}{l}\text { Kiwi fruit, orange, tangerine, watermelon, asparagus, broccoli, Brussels sprouts, cabbage, } \\
\text { carrot, collards, corn, kale, lettuce, potato, pumpkin, spinach, sweet red pepper, tomato, } \\
\text { turnip greens }\end{array}$ \\
\hline Zeaxanthin: & $\begin{array}{l}\text { Orange, persimmon, collards, corn, kale, lettuce, pumpkin, red pepper, spinach, tangerine, } \\
\text { turnip greens }\end{array}$ \\
\hline Citric acid: & Grapefruit, lemon, lime, orange, tangerine \\
\hline Saponins: & Asparagus, beet, garlic, spinach \\
\hline Caffeic acid: & $\begin{array}{l}\text { Apple, gooseberry, grape, olive, raspberry, strawberry; broccoli, Brussels sprout, carrot, } \\
\text { endive, red onion, savoy cabbage, sweet potato, tomato }\end{array}$ \\
\hline Chlorogenic acid: & $\begin{array}{l}\text { Apple, apricot, blackberry, blueberry, cherry, cranberry, grape, plum, pomegranate, } \\
\text { strawberry; cabbage, carrot, sweet red/ green pepper, tomato }\end{array}$ \\
\hline Limonene: & Grapefruit, lemon, orange, tangerine, carrot, celery \\
\hline
\end{tabular}


Table.2 State-wise area and production of fruit crops, 2013-14 to 2014-15

A: Area in '000 ha

P: Production in '000 Tonne

\begin{tabular}{|c|c|c|c|c|}
\hline \multirow[t]{2}{*}{ States/UTs } & \multicolumn{2}{|c|}{ 2013-14 } & \multicolumn{2}{|c|}{ 2014-15 (Advanced estimate) } \\
\hline & Area & Production & Area & Production \\
\hline $\begin{array}{c}\text { Andaman and Nicobar } \\
\text { Islands }\end{array}$ & 3.55 & 29.73 & 3.58 & 33.88 \\
\hline Andhra Pradesh & 640.05 & 10510.56 & 642.29 & 10114.15 \\
\hline Arunachal Pradesh & 89.09 & 321.26 & 90.00 & 331.40 \\
\hline Assam & 144.68 & 2007.80 & 155.51 & 2242.74 \\
\hline Bihar & 302.07 & 4013.58 & 303.95 & 3999.49 \\
\hline Chhattisgarh & 212.89 & 1930.18 & 226.50 & 2065.47 \\
\hline Goa & 11.28 & 81.19 & 11.34 & 81.78 \\
\hline Gujarat & 370.76 & 8001.96 & 370.76 & 8001.96 \\
\hline Haryana & 50.59 & 554.90 & 52.53 & 650.00 \\
\hline Himachal Pradesh & 220.71 & 866.34 & 220.71 & 722.98 \\
\hline Jammu and Kashmir & 355.21 & 2073.94 & 359.09 & 1542.68 \\
\hline Jharkhand & 94.03 & 890.04 & 94.14 & 898.08 \\
\hline Karnataka & 396.00 & 6652.42 & 407.27 & 6941.88 \\
\hline Kerala & 376.95 & 2889.50 & 263.51 & 2835.79 \\
\hline Lakshadweep & 0.22 & 0.48 & 0.22 & 0.48 \\
\hline Madhya Pradesh & 203.79 & 5696.00 & 214.38 & 9756.63 \\
\hline Maharashtra & 1565.00 & 13457.92 & 606.94 & 9756.63 \\
\hline Manipur & 54.05 & 515.69 & 55.61 & 532.97 \\
\hline Meghalaya & 35.30 & 348.00 & 36.01 & 375.83 \\
\hline Mizoram & 57.55 & 343.90 & 66.14 & 386.62 \\
\hline Nagaland & 40.56 & 411.00 & 40.56 & 411.00 \\
\hline Odisha & 325.86 & 2148.27 & 325.76 & 2134.60 \\
\hline Puducherry & 0.64 & 12.58 & 0.56 & 14.17 \\
\hline Punjab & 76.59 & 1541.24 & 78.70 & 1742.97 \\
\hline Rajasthan & 37.40 & 581.78 & 38.61 & 618.98 \\
\hline Sikkim & 16.02 & 24.05 & 17.59 & 26.42 \\
\hline Tamil Nadu & 328.55 & 7369.86 & 344.97 & 8107.39 \\
\hline Telangana* & 364.48 & 4440.98 & 370.56 & 5565.84 \\
\hline Tripura & 68.38 & 786.35 & 67.27 & 563.50 \\
\hline Uttar Pradesh & 378.97 & 6887.45 & 462.76 & 8541.60 \\
\hline Uttarakhand & 171.62 & 678.4 & 202.22 & 758.31 \\
\hline West Bengal & 223.50 & 2909.71 & 228.25 & 3298.70 \\
\hline Total & 7216.31 & 88977.41 & 6358.27 & 88819.26 \\
\hline
\end{tabular}


Table.3 State-wise area and production of vegetable crops, 2013-14 to 2014-15

A: Area in '000 ha

P: Production in '000 Tonnes

\begin{tabular}{|c|c|c|c|c|}
\hline \multirow[t]{2}{*}{ States/UTs } & \multicolumn{2}{|c|}{ 2013-14 } & \multicolumn{2}{|c|}{ 2014-15 (Estimated) } \\
\hline & Area & Production & Area & Production \\
\hline Andaman and Nicobar Islands & 6.89 & 51.79 & 6.91 & 51.83 \\
\hline Andhra Pradesh & 439.64 & 8149.76 & 294.76 & 5458.44 \\
\hline Arunachal Pradesh & 1.40 & 35.00 & 1.70 & 41.00 \\
\hline Assam & 281.40 & 3031.90 & 337.94 & 4647.79 \\
\hline Bihar & 809.80 & 15097.77 & 842.00 & 14467.15 \\
\hline Chhattisgarh & 403.43 & 5465.92 & 425.07 & 5812.32 \\
\hline Dadra and Nagar Haveli & 1.10 & 5.50 & 1.10 & 5.50 \\
\hline Delhi & 27.30 & 436.95 & 22.50 & 392.65 \\
\hline Goa & 7.00 & 79.92 & 7.20 & 81.94 \\
\hline Gujarat & 582.28 & 11571.24 & 578.35 & 11543.29 \\
\hline Haryana & 373.17 & 5565.90 & 375.00 & 5805.80 \\
\hline Himachal Pradesh & 86.60 & 1635.88 & 86.60 & 1638.47 \\
\hline Jammu and Kashmir & 63.06 & 1395.47 & 63.06 & 1395.47 \\
\hline Jharkhand & 313.61 & 4238.13 & 316.67 & 4279.28 \\
\hline Karnataka & 418.69 & 7500.69 & 462.86 & 8564.77 \\
\hline Kerala & 147.69 & 3572.67 & 115.43 & 2882.51 \\
\hline Lakshadweep & 0.25 & 0.33 & 0.25 & 0.33 \\
\hline Madhya Pradesh & 628.72 & 13019.31 & 649.82 & 13479.30 \\
\hline Maharashtra & 726.00 & 10161.83 & 599.86 & 8289.01 \\
\hline Manipur & 25.19 & 271.04 & 27.58 & 288.44 \\
\hline Meghalaya & 43.60 & 515.34 & 44.60 & 534.00 \\
\hline Mizoram & 41.10 & 254.14 & 45.78 & 284.81 \\
\hline Nagaland & 38.55 & 492.37 & 38.55 & 492.37 \\
\hline Odisha & 677.33 & 9433.66 & 670.35 & 93.72 .13 \\
\hline Puducherry & 0.90 & 16.26 & 2.08 & 18.84 \\
\hline Punjab & 191.02 & 3936.19 & 196.52 & 4054.08 \\
\hline Rajasthan & 148.88 & 1114.07 & 163.76 & 1237.49 \\
\hline Sikkim & 26.11 & 134.53 & 26.12 & 134.92 \\
\hline Tamil Nadu & 289.74 & 8678.82 & 305.29 & 9584.29 \\
\hline Telangana* & 220.94 & 3647.28 & 165.35 & 2740.80 \\
\hline Tripura & 46.69 & 780.52 & 35.57 & 606.08 \\
\hline Uttar Pradesh & 859.38 & 18544.96 & 1097.05 & 24515.36 \\
\hline Uttarakhand & 88.28 & 1016.83 & 90.98 & 1082.97 \\
\hline West Bengal & 1380.30 & 23044.95 & 1445.50 & 24516.95 \\
\hline Total & 9396.05 & 162896.91 & 9541.43 & 168300.38 \\
\hline
\end{tabular}


Table.4 Export of horticulture produce from India

\begin{tabular}{|c|c|c|c|c|c|c|}
\hline & & & & \multicolumn{3}{|c|}{ Qty In MT, Value in Rs Lakh } \\
\hline \multirow{2}{*}{ Products } & \multicolumn{2}{|c|}{ 2013-14 } & \multicolumn{2}{|c|}{ 2014-15 } & \multicolumn{2}{|c|}{ 2015-16 } \\
\hline & Qty & Value & Qty & Value & Qty & Value \\
\hline Fruits and vegetables seed & 17816.7 & 41053.76 & 12499.31 & 42703.80 & 10925.60 & 49353.68 \\
\hline Fresh mangoes & 41279.97 & 28542.85 & 42998.33 & 30253.66 & 36329.01 & 31710.03 \\
\hline Fresh Grapes & 192616.91 & 166647.45 & 107257.81 & 108648.99 & 156218.34 & 155131.67 \\
\hline Walnuts & 6726.36 & 32453.5 & 2665.85 & 13645.24 & 3291.71 & 11791.54 \\
\hline Other fresh fruits & 240552.45 & 102159.21 & 274436.09 & 124588.02 & 308261.23 & 153815.57 \\
\hline Mango pulp & 174860.33 & 77294.76 & 154820.66 & 84138.54 & 128866.01 & 79616.93 \\
\hline Fresh Onions & 1482498.58 & 316961.25 & 1238102.60 & 230054.14 & 1201245.29 & 274741.05 \\
\hline Other Fresh Vegetables & 953731.22 & 229332.27 & 835501.20 & 240223.60 & 699600.34 & 211949.80 \\
\hline $\begin{array}{c}\text { Cucumber and Gherkins (Prepared and } \\
\text { Preserved) }\end{array}$ & 218749.79 & 95520.18 & 251183.01 & 120242.24 & 202926.91 & 99917.20 \\
\hline Other Processed Fruits and Vegetables & 287384.61 & 226660.26 & 316059.42 & 256991.89 & 320732.58 & 290033.31 \\
\hline Dried and Preserved Vegetables & 56158.38 & 74271.74 & 63701.77 & 84713.55 & 66189.61 & 91420.90 \\
\hline Floriculture & 22485.21 & 45590.62 & 22947.27 & 46077.23 & 22518.58 & 47942.04 \\
\hline
\end{tabular}

Source: APEDA Website, May 2017

Table.5 Import of horticulture produce from India

Qty In MT, Value in Rs Lakh

\begin{tabular}{|c|c|c|c|c|c|c|}
\hline \multirow{2}{*}{ Products } & \multicolumn{2}{|c|}{$\mathbf{2 0 1 3 - 1 4}$} & \multicolumn{2}{|c|}{$\mathbf{2 0 1 4 - 1 5}$} & \multicolumn{2}{c|}{$\mathbf{2 0 1 5 - 1 6}$} \\
\cline { 2 - 6 } & Qty & Value & Qty & Value & Qty & Value \\
\hline Fruits and vegetables seed & 8198.19 & 44943.47 & 14115.24 & 61147.72 & 14328.07 & 70303.49 \\
\hline Fresh Grapes & 14717.62 & 24493.59 & 20586.18 & 37150.46 & 20340.70 & 44519.74 \\
\hline Fresh mangoes & 7.52 & 2.49 & 0.00 & 0.00 & 0.95 & 0.60 \\
\hline Walnuts & 178 & 431.08 & 1341.85 & 3620.67 & 5543.83 & 11026.52 \\
\hline Other fresh fruits & 643546.29 & 384405.46 & 742344.91 & 496298.77 & 697665.58 & 464879.03 \\
\hline Fresh Onions & 17843.88 & 3329.51 & 386.93 & 63.88 & 87323.61 & 20112.70 \\
\hline $\begin{array}{c}\text { Cucumber and Gherkins (Prepared and } \\
\text { Preserved) }\end{array}$ & 5.42 & 10.43 & 157.96 & 174.96 & 22.46 & 24.16 \\
\hline Other Fresh Vegetables & 7299.17 & 733.75 & 15863.45 & 4330.25 & 10340.91 & 1783.33 \\
\hline Dried and Preserved Vegetables & 3818.93 & 4538.19 & 3355.20 & 4188.75 & 4285.99 & 4355.09 \\
\hline Other Processed Fruits and Vegetables & 48426.32 & 54305.09 & 42453.56 & 56930.81 & 50976.53 & 60670.78 \\
\hline Floriculture & 4308.8 & 11219.43 & 4813.70 & 11326.18 & 4768.81 & 11440.01 \\
\hline
\end{tabular}

Source: APEDA Website, May 2017

Demand and Production of Fruits and Vegetables during the Last Three Years

\begin{tabular}{|c|c|c|c|c|}
\hline Year & $\mathbf{2 0 1 1 - 1 2}$ & $\mathbf{2 0 1 2 - 1 3}$ & $\mathbf{2 0 1 3 - 1 4}$ & $\mathbf{2 0 1 4 - 1 5}$ \\
\hline $\begin{array}{c}\text { Total Demand (F \& V) ('000 } \\
\text { tons) }\end{array}$ & 222750.5 & 229707.1 & 235528.2 & 239794.9 \\
\hline Production (F \&V) ('000 tons) & 232749.0 & 243471.0 & 251874.0 & 257119.6 \\
\hline
\end{tabular}

Source: - Production: - Department of Agriculture and Cooperation.

Demand: NSSO Report No 541 66th Round Survey (July 2009 June 2010)

\section{Different Marketing Channels}


Producer-trader-wholesaler-retailer-consumer.

Producer-trader-retailer-consumer.

Producer-trader-consumer.

Producer-consumer.

\section{An Efficient Marketing System Can-}

Reduce post-harvest losses.

Enhance farmers' realization.

Reduce consumer price.

Promote grading and food safety practices.

Induce demand-driven production.

Enable higher value addition.

Facilitate export.

\section{Future strategy}

To combat the wide spectrum of spoilage, National Horticulture Board (NHB), besides few other agencies like APEDA, MFPI, NCDC etc. started schemes during the IX Plan on the commercial production and management of post-harvest related infrastructural facilities at various levels of operation. The results shown by these programmes in a short span of time are indicative of the fact that the infrastructure so created has not only helped in reducing the losses to a significant level, but avenues of export have also been strengthened. The type of infrastructure created so far is the combination of individual components like grading/packing centers, pre-cooling units, cold storages, platform for collection of produce, transport vehicle and plastic crates/CFB boxes etc. For an integrated development of horticulture industry and also to achieve our targets for feeding the population as well as for meeting the requirements of the processing industry and exports, emphasis on quality production needs to be integrated with post-harvest management of the highly perishable horticultural crops. Considering the role horticulture has to pay and the constraints in its development and the mandate of doubling food production and reducing the gap between requirement and availability, the following thrust areas are identified to be given due consideration for better development of horticulture:

To act as a catalytic organization for providing technical/financial support for all round development of horticulture sector, emphasis should be laid on increasing production with an objective of achieving complete nutritional security.

Encouraging adoption of appropriate postharvest management technologies for maximizing return to the farmers/growers.

Feasibility studies for setting up the marketing, processing plants, cold storage, transportation system for raw and processed perishable horticultural products and other related fields and undertake designing, planning and execution of projects on their basis.

Promotional activities to give boost to the process of employment generation, increase income of small and marginal farmers and involvement of women and backward communities in the horticulture development process.

To encourage shifting food habits from quantity food to quality food through increased availability and mass media promotion of health oriented benefits of the consumption of fruits and vegetables. 
To stimulate private investment particularly in the fields of infrastructure, marketing and research and development with particular emphasis on the special needs of processing industry and exports.

In the world economy, the horticulture crops are very important in the high nutritional value supply of human life. The Fruits and Vegetables $(\mathrm{F} \& \mathrm{~V})$ sector has been a driving force in stimulating a healthy growth trend in Indian agriculture. It plays a unique role in India's economy by improving the income of the rural people. Cultivation of these crops is labor intensive and as such they generate lot of employment opportunities for the rural population. Fruits and vegetables typically constitute an essential part of the daily diet in India and they are in great demand round the year from most sections of the population. The commercial value of fruits and vegetables in terms of direct consumption, processing as well as trade has risen substantially in recent years. Still many rural people are deprived of fruits and vegetables consumption due to poverty and the fresh horticultural produces are becoming a food and diet only of the rich but once farmers were made to produce for themselves and for market, fruits and vegetables prices would get reduced and all section of people can enjoy it and maintain a good dietary pattern and keep up a better health. For an integrated development of horticulture industry emphasis on quality production needs to be integrated with appropriate post-harvest management of horticultural crops. Government and private operators have to join hands to improve the physical infrastructure, information sharing and the service required for quality improvement of the supply chain. If concerned effort is made by all the stakeholders, there is every possibilities that India emerges as the leading horticultural crops producing, processing, exporting and consuming country in the world.

\section{References}

Amarasinghe, U.A., Shah, T., Turral, H. and Anand, B., 2007. India's water futures to 2025-2050: Business as Usual Scenario and Deviations. IWMI Research Report 123. Colombo, Sri Lanka: International Water Management Institute.

Anonymous, 2014. Handbook on Horticulture Statistics, Horticulture division, Ministry of Agriculture, Department of agriculture and cooperation, GOI, New Delhi, India.

APEDA. 2017 http://apeda.gov.in/apedawebsite/six_he ad_product/FFV.htm.

Ashturker, B.M., and C.D. Deole, (1985). Producers' Share in Consumers Rupee: A Case Study of Fruit marketing in Marathwada, Indian J. Agric. Econ. 40: 3.

ASSOCHAM, 2013. Horticulture Sector in India- State level experience. New Delhi: The Associated Chamber of Commerce and Industry of India.

Barratt-Fornell, A., Drewnowski, A. 2002. The taste of health: nature's bitter gifts. Nutr. Today. 37: 144-150.

Holden, J.M., Elridge, A.L., Beecher, G.R., Buzzard, I.M., Bhagwat, S., Davis, C.S., Douglass, L.W., Gebhardt, S., Haytowitz, D. and Schakel, S. 1999. Carotenoid content of US foods: An update of the database. J. Food Comp. Anal. 12: 169-196.

Joshi, P.K., Gulati, A., Birthal, P.S. and Tewari, L. 2004. Agriculture diversification in south Asia: patterns, determinants and policy implications. Economic and Political Weekly, 39(24): 2457- 2467.

Kaul, G.L., 1997. Horticulture in India: Production, marketing and processing, Indian J. Agric. Econ. 52: 3.

Kumar, M.P., 2012. A study on problems of 
marketing vegetables in farmers market. Int. J. Rural Dev. Manag. Stud. 6(1): 241-251.

Martin, R.A., and Luxton, P. 2005. The successful commercialisation of ZESPRI Kiwifruit. Acta Hort. 694: 3540.

Mayo Clinic, University of California Los Angeles and Dole Food Company Inc., eds. 2002. Encyclopedia of Foods. A Guide to Healthy Nutrition, San Diego, CA, Academic Press.

Pennington, J.A., 2002. Food composition databases for bioactive food components. J. Food Comp. Anal. 15: $419-434$

Perry, C.A., Dwyer, J., Gelfand, J.A., Couris, R.R. and McCloskey, W.W. 1996. Health effects of salicylates in foods and drugs. Nutr. Rev. 54: 225-240.

Saikia, T. N., 1985. Price Structure of Pineapple: A Study in Meghalaya. Indian Journal of Agricultural Economics. 40(3): 119-123.

Seeking calm water: Exploring policy options for India's water future Amarasinghe, U. A., Shah, T. and McCornick, P.G. 2008. Natural Resources Forum. 32: 305-315.

Singh, M., 1985. Price spread of vegetables marketing, Indian J. Agric. Econ. 40: 3. Singh, R. P., and Toppo, A. 2010. Economics of production and marketing of tomato in Kanke block of Ranchi district. Indian Journal of Agricultural Marketing. 24 (2):1-16.

Singh, Ram and K S Suhag. 2010. Role of state agricultural marketing board in marketing development in Haryana. Indian Journal of Agricultural Marketing. 24 (1):38-48.

Smith, S.A., Campbell, D.R., Elmer, P.J., Martini, M.C., Slavin, J.L., and Potter, J.D. 1995. The University of Minnesota Cancer Prevention Research Unit, vegetable and fruit classification scheme (United States). Cancer Causes Control. 6: 292-302.

Subbanarasaiah, N., 1991. Marketing of Horticultural Crops in India, Anmol Publishing Co., Delhi.

Weinberger, K., and Lumpkin, T. 2005. Horticulture for poverty alleviation: The unfunded revolution: AVRDC - The World Vegetable Center.

WHO. 2002. National cancer control programmes. Policies and managerial guidelines, 2nd edition, Geneva, World Health Organization.

\section{How to cite this article:}

Neeraj, Akshay Chittora, Vinita Bisht and Vishal Johar. 2017. Marketing and Production of Fruits and Vegetables in India. Int.J.Curr.Microbiol.App.Sci. 6(9): 2896-2907. doi: https://doi.org/10.20546/ijcmas.2017.609.356 